\title{
Teaching irrigation science and water management: accepting professional diversity. Editorial
}

\author{
Jacob W. Kijne
}

Received: 19 May 2010/Accepted: 8 October 2010/Published online: 27 October 2010

(C) Springer-Verlag 2010

Water matters in a world that will soon have to grow food for billions more people. In that context, how should we educate aspiring professionals in the field of irrigation and water resource management? Before attempting an answer to that question we need to explore how the practice and science of irrigation have changed in recent decades.

First, we outline the history of irrigation development, identifying the important research issues that were characteristic for each period. The intent is to delineate major trends in the profession, highlighting those changes with implications for university curricula in irrigation and water management. The second part of the paper reviews selected curriculum reform literature and discusses the practicalities of changing from a disciplinary curriculum to multi- or interdisciplinary teaching and research in irrigation and water management. The final section discusses the desired difference between the irrigation curriculum and the water management curriculum.

\section{The history of irrigation science and practice with a focus on developing countries}

\section{Irrigation expansion}

Half a century ago, irrigation was considered one of the branches of civil engineering, rather than a scientific endeavor. Hydraulics, hydrology, soil science (mechanics,

Communicated by R. Evans.

J. W. Kijne $(\square)$

Water Management Consultant, 616 E Street NW,

Unit 718, Washington, DC 20004, USA

e-mail: jacobwillem628@msn.com physics and chemistry), and economics constituted the scientific basis for irrigation engineering. The goal-the so-called 'hydraulic mission'-during this period, lasting from the end of World War II till about the 1970s, was the construction of irrigation systems. The design and construction of hydraulic control and measurement structures were based on hydraulic principles that facilitated controlled flow in open channels and closed conduits for piped distribution systems and sprinkler irrigation. ${ }^{1}$ Hydrology dealt with the study of rainfall patterns and runoff models and studied the loss of water through evaporation and transpiration from cropped land. Several algorithms were developed for the calculation of actual and potential evapotranspiration from sets of meteorological data. Together, hydraulics and hydrology were essential for the design of large dams and reservoirs for water storage to be used for irrigation and hydropower, especially in the US (for example along the Colorado River), but also in the Indian subcontinent. The construction of such dams required the study of soil mechanics.

Chiefly in South Asia, this period also marked the beginning of an increase in water supplies for irrigation through public and private development of groundwater. Combined with other inputs of the green revolution, irrigated agriculture contributed much to achieving food security and poverty reduction in countries which hitherto had been plagued by periodic famines. The study of groundwater hydrology expanded with the development of groundwater as an additional source of irrigation water.

\footnotetext{
1 See also Horst (1998), especially chap. 1 in which the author examines irrigation development over time in support of his proposition that the design of the physical canal system with its related operational requirements limits the available irrigation management options.
} 
The study of water quality was added to the mix of supporting sciences when increased salinity of irrigated lands started to affect soil structure and crop yields. Already in 1954, the Soil Salinity Research Institute in Riverside, California, published a seminal book on soil salinity and alkalinity, based on recently improved understanding of soil chemistry and soil physics (United States Salinity Laboratory Staff 1954). Developments in soil physics increased the understanding of water movement and storage in soil profiles, as well as of the energy requirements for water uptake by crops in a drying soil. Also in this period, crop science started to provide information about the water requirements of different crops and their most sensitive periods for water stress. The Food and Agricultural Organisation of the UN was instrumental in reviewing the relevant literature and collating the results in Handbooks (e.g., Doorenbos and Pruitt 1977). At about the same time Stanhill (1978), the first chief editor of Irrigation Science wrote in the first issue of this journal: 'Scientific research has contributed much to the increased efficiency now possible. Indeed, some of the most striking scientific advances in the fields of soil physics, plant physiology and micrometeorology achieved during the last 50 years have been concerned with the status and movement of water in the soil-plant-atmosphere continuum. That this increased understanding can now be translated into field practice is due to technological advances which allow the precise control and measurement of water distribution in space and time'.

In the 20 years from 1961 to 1980 , the worldwide irrigated land area increased from about 138 to 210 million hectares (IWMI 2002). Over 90 percent of all large dams (defined as dams with a height of $15 \mathrm{~m}$ or more) were constructed after World War II, but after the decade of the 1980 s, dam construction sharply decreased. At the end of the twentieth century, there were about 45,000 large dams, two-thirds of which were between 15 and $30 \mathrm{~m}$ high. The US has 6,400 and India just over 4,000 of such large dams. A large part of the world's food and energy production still depends on these dams, but their performance has been highly variable, some falling short of physical targets and many were less economically profitable than expected. (World Commission on Dams 2000). ${ }^{2}$ The Canadian hydrologist Klemeš (2000) attributes the low performance of dams to the inherent complexity of geophysical processes and the limitations of hydrological modeling, especially with respect to rainfall-runoff analyses. Erosion and sedimentation continuously alter the hydraulic

\footnotetext{
2 The reasons for the decline in World Bank funding for large dams and the controversy around the report by the World Commission on Dams are beyond the scope of this paper. The interested reader is referred to Briscoe (2010).
}

conditions of river channels and thereby have a permanent and irreversible effect on runoff. Urbanization and deforestation cause further modifications in the hydrological processes.

\section{Increased complexity}

In the 1980s and 1990s, the dominant strategy in irrigation development shifted from construction to performance evaluation. The optimism that irrigation performance could be much improved is expressed by Singh (1994) in an editorial introducing a special issue of Irrigation Science. He writes: 'An accurate simulation of the entire irrigation cycle is now within our reach; design of surface irrigation systems is much improved as a result', and 'There can be little argument that future planning, design operation, and management of irrigation systems will have to be based on more advanced and accurate models of surface irrigation'.

World Bank lending for agriculture decreased considerably in the decade to 2000, parallel to lending for rural development that declined from about 30 percent in 1978-1981 to 17 percent of their total portfolio in the early to mid-1990s. New irrigation construction largely stopped, and the emphasis moved to sustaining and improving the efficiency of existing systems. The irrigated area in the world increased only from 210 to 280 million ha during the last two decades of the century. Although investments on irrigation and drainage still accounted for about one-third of the rural portfolio, the focus was on the rehabilitation of existing infrastructure and devolution of responsibilities to water user associations (Thompson 2001). World Bank strategy at the time linked the future of irrigation development with addressing the environmental problems related to irrigation management. The Bank's priority issues included the control of waterlogging and salinity through improved water management and adequate drainage, the disposal of drainage water, and ensuring sufficient environmental stream flows through regulating extractions of water for irrigation. This change in focus aimed to address oversights and weaknesses in the design and implementation of previous projects. One of the recognized weaknesses was insufficient attention to drainage in past irrigation investments, leading to reduced agricultural productivity because of increased soil salinity.

When the performance of existing irrigation systems is being emphasized, irrigation science and practice depend less on (civil) engineering and more on knowledge and information that comes from a combination of crop science, agro-hydrology, and soil physics on the one hand and management science on the other. As Singh (1994) predicted, irrigation performance evaluation has been advanced by the development of deterministic models to simulate water flow and salt transport in farmers' fields. 
The soil and crop data input are obtained in the field or laboratory, while the soil hydraulic functions valid under field conditions are calculated using an algorithm (e.g., Van Dam et al. 1997).

The management of irrigation systems and options for farmer participation and comanagement are an important part of the performance assessment studies. To raise the effectiveness of irrigation water, researchers study farm level water distribution. This had hitherto largely been ignored since system design rarely included water distribution below the level of secondary canals (e.g., Horst 1998). As canal water and pumped groundwater are increasingly used together, their conjunctive management has become an integral part of the efforts to improve irrigation efficiency. In some semiarid countries, e.g., in the Middle East and Pakistan, much of the pumped groundwater is saline, which requires leaching of the root zone with an adequate amount of good quality canal water. Soil salinization and waterlogging therefore continue to be essential areas of research (Kijne 2003). The use of good quality canal water for leaching of the soil profile puts an extra burden on water management at farm level.

Often one of the causes of poor water delivery performance is a mismatch between the management-imposed water distribution rules and the delivery pattern that farmers prefer and believe is technically feasible. If this happens, water users will try to subvert the rules. Moreover, non-observance of water distribution rules occurs often and usually favors farmers in the head reaches of tertiary canals over the tailenders. In the 1990s, expectations were high that the transfer of irrigation management from government institutions to water users associations would improve water use efficiency at the level of tertiary canals that supply water directly to (groups of) farms. It was also hoped that when farmers were made responsible, the collection of water fees would improve. Some irrigation management transfers programs are indeed successful, especially if the infrastructure was improved before transfer took place. Clemmens and Molden (2007) discuss recent work on performance assessment in a special issue of Irrigation Science entitled 'Irrigation Science on Water productivity: science and practice'. They studied the link between the quality of service delivery and the efficiency and productivity of the water use and found this relationship to be elusive. These authors conclude that 'Substantive improvements in performance are not possible by making big improvements at only one level within the system. Physical and management improvements may need to be made at all levels before substantial improvements in performance can result'. More recently, further studies confirm that improving agricultural water productivity is not as easy as once thought (e.g. Molden et al. 2009).
Also, as Shah et al. (2002) argue, even when all conditions for successful management transfer are met, it is still unlikely to work for irrigated smallholder farming in Africa. They maintain that an entire complex of constraints facing smallholders needs to be addressed before they can take the responsibility of managing their own irrigation systems. Whether the smallholder production system is no longer viable or continues to be one of the most crucial farming systems, enabling poor households to gradually escape from rural poverty, remains controversial.

Irrigation development in the USA

The history of water resources development in the US can also be arranged in different periods. Turral (1998) lists a number of historical landmarks in the history of water development. Citing Frederick (1991), he characterizes the period of $1900-1920$ as private versus public water exploitation, 1921-1932 as the period during which the federal role in water development was increasing, while during 1933-1944 the emphasis was on the economic development of water resources, consistent with the New Deal of the Roosevelt administration. The post WW II period till about 1970 is characterized by the realization of economic and environmental limits, whereas since then the emphasis has been on meeting current and future water use with a gradual diminishing importance of food production and growing attention to the role of water in the environment. The increasing complexity of irrigation science and practice is a theme that runs also through the history of irrigation in the US.

\section{Irrigation development in Asia}

Describing the evolution of irrigation in South and Southeast Asia, Barker and Molle (2004) identify three separate time periods: the Colonial Era (1850-1945), the Cold War period (1946-1989), and the new era of Globalization from 1990 onwards. These authors see significant differences in the development of institutional and physical infrastructure between East Asia on the one hand and South and Southeast Asia on the other. They perceive that social and economic objectives tended to impel the development of irrigation during the Colonial Era. This motivation continues today as national governments and multilateral lending agencies finance irrigation development. However, the emphasis has varied over time between social objectives such as poverty alleviation and food security, and the economic objectives of increased tax revenue and growth in the value of agricultural production.

The dominant strategies identified for the Colonial Era are protective irrigation in semiarid regions for famine prevention in years of drought and water diversion schemes 
in the monsoonal regions to secure the main harvest, collect revenue, and prevent flooding (Barker and Molle 2004). The distinction between protective and productive irrigation is still relevant. There often is tension between these two objectives, culminating in questions about financing of infrastructure and collection of water fees. The large canal irrigation systems in the Indo-Gangetic Plain, designed to spread the water thinly over a large area, are examples of protective irrigation. In water-short years, all farmers are expected to share equally in the shortfall. These systems are supply driven and not designed to meet the full crop water requirements for the entire command area; as a result, profits are low and water charges are low or nonexistent. In main canals, the supply is continuous, and in secondary and tertiary canals, the supply is usually rotated between (groups of) famers. This rotation system has been practiced in the Indian sub-continent from the beginning of irrigation and continues to this day although with many changes that have resulted from population pressure, neglect of infrastructure, and the more recent development of tubewells (Bandaragoda 1998; Shah 2009). After independence of the former colonies, the strict discipline required for the irrigation systems to work could no longer be maintained, operational standards declined and farmers increasingly took matters of water delivery in their own hands. Similarly, post-independence farmers rejected the strict soil conservation rules in East Africa that were imposed by the colonial government.

The irrigated paddy (rice) fields of Indonesia and other South Asian countries are an example of irrigation in monsoonal regions. The rice fields were first developed in the seventeenth and eighteenth centuries to support the growing population and only later for the production of cash crops. In Indonesia, for example, Dutch engineers expanded the irrigation systems to grow sugarcane on a commercial basis. In the first half of the twentieth century, until World War II, hydraulic infrastructure in Indonesia was greatly increased to nearly triple the area under rice. Elsewhere in South Asia, large infrastructural developments took place in river deltas that facilitated the production of large quantities of rice for local consumption and for export (Barker and Molle 2004).

Irrigation as part of rural development

Toward the end of the twentieth and the beginning of the present century, irrigation practice transformed itself into water resource management and became more and more part of development science. This implied a greater role for the social sciences in the evaluation of irrigation. Started already when irrigation performance became the central focus, the discourse on irrigation increasingly includes topics such as the role of irrigation in food security and poverty alleviation. As we have seen, protective irrigation, i.e., to prevent famines, has always been one of irrigation's goals, but the prevention of famines has received renewed attention because of the growing awareness that water is scarce and the continued population growth, especially in developing countries.

The impact of irrigation on rural poverty has been studied extensively, especially in India (Bhattarai and Narayanamoorthy 2003; see also Namara et al. 2010). Researchers have found that the marginal impact of irrigation followed by that of rural literacy explained more of the variation in the rural poverty level in India than any of the other input factors, such as the adoption of high-yielding varieties or the density of rural roads. The marginal impact of groundwater irrigation exceeds that of canal irrigation due to the greater control by farmers over the timing and amount of groundwater application. The evidence, however, is incomplete as other studies, notably by Fan et al. (2000), report that the government's investment in agricultural research and development and on rural road infrastructure has greater impact on rural poverty in India than did irrigation. Lipton et al. (2003) in a thoughtful paper point out that there are important regional differences. For example, they believe that substantial poverty reduction in sub-Saharan Africa is unlikely to be achieved without additional small- and large-scale irrigation projects.

Small-scale irrigation technology, such as trickle irrigation and the use of treadle pumps, also receives much attention as these technologies can improve the livelihoods of poor farmers in regions where water is available to invest in irrigation. They boost agricultural production and enhance food security. The overall adoption of these technologies, however, is still quite low; in 2006, microirrigation was practiced worldwide on slightly more than 6 million ha, out of a total of 277 million ha irrigated land (based on International Commission on Irrigation and Drainage data, Reinders 2006). Also, there are serious policy impediments (e.g., no financial incentives for manufacturing and maintenance of the technologies and no programs targeting specific groups of poor farmers) to successfully enlarging the area where these technologies are applied.

Irrigation economics

There is an agreement that the era of massive public investments in irrigation infrastructure is over, and in most countries, ${ }^{3}$ irrigation development has shifted from the construction of heavy infrastructure to improving the regulation, control, and conveyance of water (Turral et al.

\footnotetext{
3 With the exception of India and China which continue to expand and physically improve their irrigation systems.
} 
2010). Contentious, however, is whether additional demand for food will require large investments in additional irrigation systems or that this demand can be met from increased area and yields from rain-fed land. Presently, about 40 percent of the world's food is grown on less than 20 percent of its cultivated area, compared with 20 percent on 15 percent of the cultivated land in 1978 (Stanhill 1978). If the share of food produced on irrigated land increases even more, as some predictions have it, additional irrigation infrastructure will probably be necessary. The recent spike in world food prices and the significant use of crops for the production of biofuel have added to the concern about water use in agriculture (e.g., De Fraiture et al. 2008). Many scientists, including plant breeders and irrigation engineers, are now working on raising the productivity of water in irrigation (Molden et al. 2009).

Water pricing has often been suggested as a means to induce irrigators to use water more sparingly, and it remains a research topic. How to impose water charges and the level of an appropriate water charge remain controversial, especially when irrigation water serves a social function as a source of domestic water. Water managers rightly think that charging a service fee to cover at least the operation and maintenance cost of water delivery services is a valid practice. But farmers are not inclined to pay water charges unless they know the fees collected will be used for maintaining and operating their systems. There is evidence that charging for water is more likely to succeed if several institutional arrangements are in place. These include that (1) the water resource has been assessed, (2) water rights are assigned, and (3) the institution that administers these rights has been established, (4) the charges are fair and transparent, and (5) the institution can be held accountable (Perry et al. 1997; Easter and Liu 2007; Shah 2009).

Water interactions in river basins are complex and sitespecific. One ongoing research topic is the effect of upstream water harvesting and water use on downstream river flow and on groundwater recharge and hence on the availability of groundwater for pumping. The underlying principle is that water can be used only once in a river basin for evapotranspiration from crops. This awareness has led in recent years to renewed interest in the management of transboundary rivers (Wolf 2003).

Given this increasing complexity in the field, the question becomes how the next generation of engineering students should be educated to effectively address the conundrum of an increasing demand for water for food production in the face of urban expansion and environmental water demands, at a time when these conflicting demands are occurring in the context of changing rainfall patterns and extreme weather events as a result of global warming.

\section{Teaching irrigation and water resource management}

\section{Changes in engineering courses}

A worldwide review of university courses designed to educate irrigation and water management engineers or scientists exceeds the range of this paper; here, we focus instead on programs at US universities. The US university system can serve as an example for universities elsewhere; not only does it represent the dominant culture but it is also where many of the university staff in developing countries where irrigation is practiced, received their training. Even countries that were never colonized, such as Thailand, China, and Ethiopia, chose to adopt the western academic model of education (Altbach 2009).

Another reason for focusing on American universities is that university training of irrigation engineers in Western Europe is less representative of the general trend. Historically, some universities in the UK, France, and the Netherlands prepared irrigation engineers for a professional career in the colonies. After independence of the former colonies, the need for training irrigation engineers and scientists declined and the universities gradually developed interdisciplinary programs with development science as a focal point. In contrast to the predominantly large-scale civil engineering orientation of irrigation engineering worldwide, irrigation teaching in some European universities was conducted at an agricultural university and focused on the field and farm level (e.g. Wageningen University). Several of the Western European universities now have strong interdisciplinary programs on environmental issues and agricultural sustainability (including, for example, the University of Essex, Cranfield University and the School of Development Studies of the University of East Anglia in the UK).

As a result of directives from the European Union, European universities are in the process of changing to shorter duration bachelor's and master's degrees to replace the traditional 5- or 6-year first degree programs. Entrance requirements for these bachelor programs are lighter than those for the previous, longer programs. Moreover, these changes will make universities across the EU more compatible and-as is expected-will lead to more useful degrees. It also makes them look more like the US system of a 4-year bachelor's program that is followed by a master's degree for only a portion of the first degree graduates.

India and China, the two leading countries in terms of irrigated acreage, are still expanding their irrigated area, and many Asian institutions still have strongly technical and disciplinary-focused curricula with hardly any agriculture-related topics (Sundaram 2009). In much of Asia irrigation, practice and education has not moved toward a 
multidisciplinary approach, but according to Mashelkar (2010), many changes are currently taking place in Indian universities.

The case for and against curriculum reform

In recent years, several presidents of US professional societies have expressed their concern about the content of engineering curricula and the low student intake in faculties and departments of engineering. Typical is the 1998 lament by the then president of the US National Academy of Engineering, W. A. Wulf: 'We need to understand why in a society so dependent on technology, a society that benefits so richly from the results of engineering, a society that rewards engineers so well, engineering isn't perceived as a desirable profession' (cited in Ball 2010). There are numerous proposals for engineering education reform; one of the more detailed is that prepared by the National Academy of Sciences (NAS 2005), which will be discussed below. The tenet of this report is supported by Galloway (2007), former president of the American Society of Civil Engineers, who writes 'If engineers are relegated to the role of technicians they will no longer command the levels of responsibility that will enable them to successfully compete in the global economy or assume the leadership roles that will enable them to elevate standards of living worldwide and provide enhanced protection to the environment'.

The modern research university is premised on the early twentieth century notion that professionals would gain prestige by establishing their training and education in universities. According to Schön (1987, cited in Dall'Alba 2009): 'Practical competence becomes professional when its instrumental problem solving is grounded in systematic, preferably scientific knowledge'. The status of the professionals is assumed to depend on the extent to which they can present themselves as rigorous practitioners of knowledge acquired from the basic sciences. Good practice should then follow from theoretical knowledge that makes it possible to predict the consequences of actions in the world and therefore to be able to control these events. This belief gave rise-among other things - to an engineering curriculum that was heavily biased toward the basic sciences.

The functional fit between professional education based on this normative curriculum and professional practice has recently been questioned. Dall'Alba (2009) argues in her book that the way universities currently educate professionals is limited in scope and inadequate in preparing them for the many types of professional practice. Although overtime innovations were introduced in the normative curricula, the organization of the curriculum remained the same. Alternatives such as problem-based and work-based learning remain exceptions, and they have their own limitations. In problem-based learning, students are often given a problem to solve before they have been presented with the necessary knowledge. Some students find this frustrating. Dall'Alba (2009) reports, not surprisingly, that results suggest that medical students from normative curricula demonstrate better knowledge of basic sciences, but that those in problem-based programs may show better clinical knowledge. In 2008, the Journal of Contemporary Water Research and Education published a special issue (vol 139) entitled 'A creative critique of US Water Engineering', which bundled short papers by a number of experienced water specialists. Howe (2008) in the preface of this issue remarked that the papers raise the old question of 'how much can be taught in the university or college and how much must be acquired through experience'. Some authors maintain that a solid technical base is essential for new water management and environmental graduates. These voices come largely from project engineers working as consultants or in agencies such as the US Army Corps of Engineers and the Bureau of Reclamation that recruit engineers who traditionally received their academic training within a single discipline such as civil engineering (e.g., DiNatale 2008; Bourget 2008). DiNatale (2008) distinguishes three stages in the typical engineering career: the first phase emphasizes the acquisition and use of technical and analytical skills; the second phase develops and uses project management skills; and the third phase emphasizes the development and sustaining of good client relationships.

The other side of the argument is presented by Layzer (2008) who points out that educators hoping to train effective water professionals need to 'expose their students to the social, institutional and political dimensions of water'. He emphasizes that what really needs to be managed is not water, but the impact of human activities on aquatic systems.

Looking for ways to broaden engineering education and to better prepare graduates for work in today's society, the US National Academies of Sciences (NAS 2005) suggests that engineering programs should be accredited at both the B. Sc. and M. Sc. levels. The M. Sc. level should be recognized as the engineering professional degree, somewhat similar to the medical and law degree programs. The NAS report makes no attempt to define a core curriculum as it considers that all institutions should design their own: 'In addition to producing engineers who have been taught the advances in core knowledge and are capable of defining and solving problems in the short term, institutions should teach students how to be lifelong learners'. Educators are encouraged to introduce interdisciplinary learning in the undergraduate curriculum. Many commentators (e.g. Loucks 2008) concur that the level of knowledge engineers 
needs to effectively manage water resources is beyond the scope of the traditional B. Sc. degree program.

Interestingly, in 2002 the US Army Corps of Engineers, in partnership with the Universities Council on Water Resources, launched an M. Sc. program consisting of several interdepartmental curricula (Bourget 2008). Selected courses would expose students to topics of economics, law, hydrology, engineering, ecology, and participatory planning. Unfortunately, the targeted training budgets available in previous years were either terminated or significantly curtailed by the time the program was ready. In the absence of centralized training opportunities, individual Corps districts had to fund the students from their own budgets.

Since then, several US universities have started interdisciplinary curricula in water resources management for the simple reason that modern water resource management is very complex (e.g. Lenton and Muller 2009). This is especially apparent at larger scale. As alluded to before, the complexity of hydrologic interconnections at watershed or river basin level makes the effects of management interventions unpredictable (Molden et al. 2009).

Are interdisciplinary courses more attractive to students?

Another pressing issue regarding engineering teaching, especially in the US, is how to expand engineering enrollment at the undergraduate and higher levels. It has been argued that students are more likely to enroll in an interdisciplinary program than in the traditional engineering courses. Perhaps, students perceive the nonengineering ('soft') courses as easier than the mathematical and physical sciences at the core of engineering curricula (Stefani 2009). But, according to Rogers (2008), the lack of financial incentives explains the fact that few US students chose to major in engineering and many of the graduates accept jobs outside of the engineering profession. Rogers (2008) quote figures showing that US PhD's in engineering and science have lifetime earnings that are on the order of $\$ 3$ million less than doctors and $\$ 1.8$ million less than lawyers. Engineering jobs in the US are open to foreigners (much more so than for legal or medical graduates), and there is also considerable outsourcing of engineering jobs to foreign countries. Both contribute to the salary differences. In addition, water is considered a public good and those who manage water resources are often associated with government agencies (Louck 2008). Rogers (2008) thinks that academic funding for civil and environmental engineering in the US is not keeping up with inflation, and there is little industrial support when compared with what is available for other engineering specialties. Upgrading applied research in civil and environmental research, better professional training, and raising the remuneration for the practitioners would improve the incentives to encourage students to enroll in engineering and to stay in the profession after graduation (Rogers 2008).

Interdisciplinary and multidisciplinary research and teaching

Often interdisciplinary research and interdisciplinary education are not well defined, and educators and researchers appear to have different ideas about what these terms mean. Stakhiv (2008), attempting to clarify the use of the terms, specifies that individual disciplinary research produces knowledge for that particular discipline, whereas interdisciplinary research or teaching projects 'provide a synthesis of knowledge that better address complex real world problems'. He then continues to make a distinction between multidisciplinary problem solving and synthesis versus interdisciplinary education and training. Multidisciplinary teams are needed to solve the complex issues of water resource management, and these teams consist of experts in their own fields, such as economics, hydrology, or ecology. As the experts gain experience in multidisciplinary teams, they acquire greater understanding of the other disciplines and become interdisciplinary synthesizers. This supports the argument of the National Academies of Sciences (2005) that the knowledge needed to effectively manage water resources exceeds what can be taught in the traditional B. Sc. engineering curriculum.

\section{Practical aspects of introducing multidisciplinarity}

Several papers in the special issue of J. Contemporary Water Research and Education discuss the obstacles encountered when starting multidisciplinary university courses. There is evidence that multidisciplinary degree programs tend to compete with disciplinary departments for resources, students, and faculty loyalties. Tenure and resource allocation decisions are usually department based, and faculty members participating in multidisciplinary courses are often at a disadvantage (e.g., Dall'Alba (2009). Moreover, some universities do not fund multidisciplinary courses at the same level as department programs. The most extensive study of the challenges and pitfalls of multidisciplinary teaching and research was made by Lin (2008). Lin (2008) conducted an e-mail survey to collect data from selected Pennsylvania State University faculty members who had been involved in multidisciplinary teaching or research related to soil and water sciences. Responses show that often more than one faculty member advised graduate students in their research projects, with 
occasionally insufficient interaction between the coadvising faculty members and uncertainty about supervisory responsibilities. In general, producing the synergistic integration of multiple disciplines was often difficult as leadership was lacking and incentives for faculty and students to conduct interdisciplinary research were also inadequate. Maintaining adequate interaction between faculty members tended to conflict with departmental demands on the faculty member's time. In general, individual interpersonal relationships were found to be the most important indicators of the success or failure of multidisciplinary studies. Some faculty members were not comfortable with sharing ideas with other faculty or different disciplines (Lin 2008; Strang 2009). In short, working styles and experience govern the quality of the collaboration.

Water management and environmental studies

The formation of so-called interdisciplines in which the areas of knowledge and learning follow different methodologies than the constituent disciplines is much cheaper than the establishment of an expensive new academic department with its usual infrastructural support (e.g. Ellis 2009). Because of their complexity, water management and environmental studies have the distinct characteristics of interdisciplinarity. Increasingly, large research projects in these interdisciplinary areas require the input of many researchers from different disciplines, expensive equipment, and a rather complicated organizational structure, especially if the participating researchers are located at different institutes or in different countries. All of this implies a large multiyear budget to be funded by agencies with deep pockets. Internationally, such agencies include: the World Bank, the EU, and the regional development banks; within the US, there are the National Science Foundation (NSF) and several other scientific consortia such as the Consortium of Universities for the Advancement of Hydrologic Sciences. The Consultative Group of International Agricultural Sciences (a consortium of international agricultural research institutes) has examples of interdisciplinary research, such as its eco-regional and challenge programs and system-wide initiatives.

Some organizations that focus on specific problem areas have a built-in synergy, even if the scientists come from different disciplines. The Agricultural Research Services of the US Department of Agriculture (USDA-ARS), with 1200 research projects in 21 national programs, 100 locations, and (in 2009) an annual budget of $\$ 1.1$ billion, provides an obvious example. Within the Natural Resources and Integrated Agricultural Systems program, the research projects on water availability and watershed management and the project on Global Change are relevant in this context.

\section{Distinction between irrigation and water resource management (WRM)}

The irrigation of agricultural land requires the development, maintenance, and management of durable and efficient delivery systems that convey water from its source to the land. Design and operation of such systems are technical issues. Irrigation engineers implement allocation rules at various system levels and deliver water to its users. Although irrigation water is often used domestically, the allocation is to one category of users only, i.e., farmers or groups of farmers. As noted, irrigation research advances understanding of the scientific principles of water movement and distribution, thereby enhancing the efficiency of water use in agriculture. This increased scientific understanding combined with new technology leads to better control and the measurement of water distribution in space and time (Stanhill 1978). Current issues of Irrigation Science amply illustrate the wide range of scientific studies that contribute to maintaining and improving the productivity of irrigated lands and increasing the efficiency of agricultural water use.

Water management, however, is no longer the profession of only those who manage water in the narrow sense of being responsible for the collection, allocation, and distribution of water to and for various users, including industry, households, and agriculture. There is a multiplicity of definitions. For example, Stakhiv (2008) writes that a water manager implements policies and manages strategic planning choices, while contributing to the management of operating water infrastructure to provide reliable services. As management is performance-oriented problem-solving, he deplores the use of the term water management for policy analysts, researchers, data collectors, professors, and statisticians. Simonovic (2009) opines that WRM is a process of managing behavior, and what will work varies with the site-specific conditions of water resources and the social system being managed. Klemeš (2000) defines WRM as an ensemble of measures taken to utilize a given water resource for the satisfaction of a given set of water demands. He goes on to say that good WRM requires knowledge of how a system would react to fluctuations of its input (supply and demand) and thus an understanding of the location of bottlenecks in the system and which contingencies need to be built-in.

\section{Consequences for university curricula}

Since irrigation scientists and engineers have separate career paths from water management specialists, this should be reflected in their curricula. Each needs to be distinct and well defined. As mentioned, irrigation deals 
with the design, operation, improvement, and management of irrigation systems. Water resource management, by contrast, deals with the allocation and distribution of water to various, often conflicting, users.

The irrigation curriculum should be built on the key supporting sciences of hydrology, hydraulics, soil and plant science, and economics. Students will need to acquire skills from all these disciplines, to implement appropriate irrigation policies and manage strategic planning choices.

The water management curriculum should incorporate environmental, economic, and social studies to prepare students for participation in socio-economic development planning processes and policy formulation. These disciplines will equip graduates to find an optimal balance among economic efficiency (allocating water strategically to different economic uses), social equity (ensuring equitable access to water and its benefits), and environmental sustainability (protecting water resources for future use).

As pointed out, the presentation of knowledge in these curricula is still being debated. The proposal by the US National Academies of Science (NAS 2005) that engineering programs should be accredited at B. Sc. and M. Sc. levels, deserves to be considered seriously. Universities should experiment with various organizational structures, including multidisciplinary, for the education of future irrigation, and water management professionals. Their inputs coupled with good research and wise investments will be essential if global food requirements and water needs are to be met in years to come.

\section{References}

Altbach PG (2009) Peripheries and centers: research universities in developing countries. Asia-Pacific Edu Review 10:15-27

Ball P (2010) Making stuff: from bacon to bakelite. In: Bryson B (ed) Seeing further: the story of science $\&$ the royal society. Harper Press, London, pp 295-319

Bandaragoda DJ (1998) Design and practice of water allocation rules: lessons from the warabandi in Pakistan's Punjab. Research report 17. International Water Management Institute, Colombo

Barker R, Molle F (2004) Evolution of irrigation in South and Southeast Asia. Comprehensive assessment research report 5. International water Research Institute, Colombo

Bhattarai M, Narayanamoorthy A (2003) Impact of irrigation on rural poverty in India: an aggregate panel-data analysis. Water Policy $5: 443-458$

Bourget PG (2008) Key lessons learned from the masters degree program in water resources planning and management. J Contemporary Water Res Edu 139:55-57

Briscoe J (2010) Viewpoint-overreach and response: the politics of the WCD and its aftermath. Water Alternatives 3(2):416-422

Clemmens AJ, Molden DJ (2007) Water use and productivity of irrigation systems. Irrigation Sci 25:247-261

Dall'Alba G (2009) Learning to be professionals. Springer, London, New York
De Fraiture C, Giordano M, Liao Y (2008) Biofuels and implications for agricultural water use: blue impacts of green energy. Water Policy 10(Suppl 1):67-81

DiNatale K (2008) Needs of the consulting engineering sector and strengths and weaknesses of today's graduates. J Contemporary Water Res Edu 139:14-16

Doorenbos J, Pruitt WO (1977) Crop water requirements (revised). FAO irrigation and drainage paper 24, Food and agricultural organization, Rome

Easter KW, Liu Y (2007) Who pays for irrigation: cost recovery and water pricing? Water Policy 9:285-303

Ellis RJ (2009) "Problems may cut right across the borders": why we cannot do without interdisciplinarity. In: Chandramohan BB, Fallows S (eds) Interdisciplinary learning and teaching in higher education. Routledge, New York, London

Fan S, Hazell PBR, Thorat S (2000) Government spending, growth and poverty in rural India. Amer J Agric Econ 84:1038-1051

Frederick KD (1991) Water resources: increasing demand and scarce supplies. In: Frederick KD, Sedja RA (eds) America's renewable resources: historical trends and current challenges. Resources for the Future, Washington, pp 23-78

Galloway PD (2007) The 21st century engineer: a proposal for engineering education reform. American Society of Engineers. ASCE Press, Washington, DC

Horst L (1998) The dilemmas of water division: considerations and criteria for irrigation system design. International Water Management Institute, Colombo and Wageningen Agricultural University, Wageningen

Howe CW (2008) A creative critique of US water education: preface. J Contemporary Water Res Edu 139:1-2

IWMI (2002) World irrigation and water statistics. International Water Management Institute, Colombo

Kijne JW (2003) Water productivity under saline conditions. In: Kijne JW, Barker R, Molden D (eds) Water productivity in agriculture: limits and opportunities for improvement. CABI Publ, Wallingford and IWMI, Colombo, pp 89-102

Klemeš V (2000) Common sense and other heresies: selected papers on hydrology and water resources engineering. Canadian Water Resources Association, Cambridge, Ontario

Layzer JL (2008) Training people managers: the social and institutional dimensions of water management. J Contemporary Water Res Edu 139:34-36

Lenton R, Muller M (2009) Integrated water resource management in practice: better water management for development. Earthscan, London

Lin HS (2008) Opportunities and challenges of interdisciplinary research and education. J Nat Resources and Life Sciences 37:83-91

Lipton M, Litchfield J, Faurès J-M (2003) The effects of irrigation on poverty: a framework for analysis. Water Policy 5:413-427

Loucks DP (2008) Educating future water resource managers. J Contemporary Water Res Edu 139:17-22

Mashelkar RA (2010) Irreverence and Indian science. Science 328:547. doi:101126/science.1191057. Accessed 4 May 2010

Molden D, Oweis T, Steduto P, Bindraban P, Hanjra MS, Kijne JW (2009) Improving agricultural water productivity: between optimism and pessimism. Agric Water Manage 97:528-535

Namara RE, Hanjra MA, Castilo GE, Ravnborg HM, Smith L, Van Koppen B (2010) Agricultural water management and poverty linkages. Agric Water Manage 97:520-527

National Academies of Sciences (2005) Educating the engineer of 2020: adapting engineering education in the new century. National Academies Press, Washington, DC. (http://books.nap. edu/catalog.php?record_id=11338\#toc. Accessed 11 Dec 2009)

Perry CJ, Rock M, Seckler D (1997) Water as an economic good: a solution or a problem? Research report 14. International Water Management Institute, Colombo 
Reinders FB (2006) Micro-irrigation: world overview on technology and utilization. Keynote address at the opening of the 7th International micro irrigation congress in Kuala Lumpur, Malaysia. (http://icid.org/nletter/micro_nl2006_4.pdf. Accessed 13 Feb 2010)

Rogers PP (2008) Problems with civil and environmental engineering education in the US. J Contemporary Water Res Edu 139:3-5

Schön DA (1987) Educating the reflective practitioner: toward a new design for teaching and learning in the professions. Jossey-Bass, San Francisco

Shah T (2009) Taming the anarchy: groundwater governance in South Asia. Resources for the Future, Washington

Shah T, van Koppen B, Merrey D, De Lange M, Samad M (2002) Institutional alternatives in African smallholder irrigation: lessons from international experience with irrigation management transfer. Research report 60. International Water Management Institute, Colombo

Simonovic SP (2009) Managing water resources: methods and tools for a systems approach. UNESCO, Paris and Earthscan, London

Singh VP (1994) Editorial. Irrigation Sci 15:55-56

Stakhiv EZ (2008) Cogitations on the education of water resource managers. J Contemporary Water Res Edu 139:6-11

Stanhill G (1978) Editorial. Irrigation Sci 1:1-2

Stefani L (2009) Assessment of interdisciplinary and interprofessional programs: shifting paradigms. In: Chandramohan BB, Fallows $S$ (eds) Interdisciplinary learning and teaching in higher education. Routledge, New York, London

Strang V (2009) Integrating the social and natural sciences in environmental research: a discussion paper. Environ Dev Sustain 11:1-18
Sundaram A (2009) Theory and practice of interdisciplinarity in futures studies. In: Chandramohan BB, Fallows S (eds) Interdisciplinary learning and teaching in higher education. Routledge, New York, London, pp 140-151

Thompson R (2001) The world bank strategy to rural development with special reference to the role of irrigation and drainage. Keynote address 1st Asian regional conference and workshop, 52nd IEC meeting of ICID, Seoul. International Commission on Irrigation and Drainage, New Delhi, pp 2-17

Turral H (1998) Hydro logic? Reform in water resources management in developing countries with major agricultural water use. ODI Research Study. Overseas Development Institute, London

Turral H, Svendsen M, Faures J-M (2010) Investing in irrigation: reviewing the past and looking to the future. Ag Water Manage 97:551-560

United States Salinity Laboratory Staff (1954) Diagnosis and improvement of saline and alkali soils. Agricultural handbook no. 60. USDA, Washington, DC

Van Dam JC, Huygen J, Wesseling JG, Feddes RA, Kabat P, van Walsum PEV, Groenendijk P, van Diepen CA (1997) Theory of SWAP version 2.0: simulation of water flow and plant growth in the soil-water-atmosphere environment. Report 71 Dept. Water Resources. Technical document 45, Staring Center, Wageningen Agricultural University, Wageningen

Wolf AT (2003) The present and future of transboundary water management. In: Figuères CM, Tortajada C, Rockström J (eds) Rethinking water management: innovative approaches to contemporary issues. Earthscan, London, pp 164-179

World Commission on Dams (2000) Dams and development: a new framework for decision-making. Earthscan, London 